\title{
Nematicidal activity of leaves of common shrub and tree species from Southern Chile against Meloidogyne hapla
}

\author{
Laura Böhm, Nolberto Arismendi, and Luigi Ciampi \\ Instituto de Producción y Sanidad Vegetal, Facultad de Ciencias Agrarias, Universidad Austral de Chile. \\ Casilla 567, Valdivia, Chile.
}

\begin{abstract}
L. Böhm, N. Arismendi, and L. Ciampi. 2009. Nematicidal activity of leaves of common shrub and tree species from Southern Chile against Meloidogyne hapla. Cien. Inv. Agr. 36 (2): 249-258. The biological control of the root-knot nematode, Meloidogyne hapla, was evaluated through the addition of organic amendments of dry and chopped leaves of Buddleja globosa, Drymis winteri, Eucalyptus globulus, Gevuina avellana, Laurelia sempervirens, Luma apiculata, Maytenus boaria and Ugni molinae to the soil substratum. The assays were carried out in pots seeded with lettuce plants (cv. Reina de Mayo). All pots were inoculated with 2000 eggs and juveniles of M. hapla, and then maintained under greenhouse conditions for 45 days. Control pots without foliage additions were also seeded with lettuce. The results show that the addition of dry leaves of $L$. sempervirens, G. avellana, M. boaria, D. winteri, and $B$. globosa significantly reduced root-knot nematode development in soil in which lettuce plants were grown. On the other hand, while all of the treatments significantly affected the development of eggs and juveniles of M. hapla, the best inhibitory effect was found with dry leaves of $U$. molinae, $D$. winteri and $L$. sempervirens. For all plant species, an increase in the concentration of dry leaves incorporated into the substratum resulted in better control of nematode population.
\end{abstract}

Key words: Biological control, forestry species, Meloidogyne hapla, nematodes, organicamendment; ligneous plants.

\section{Introduction}

The most important species of Meloidogyne in Chile are M. hapla and M. incognita. These species cause root knots in a wide range of host plants (Böhm, 1986), and are prevalent in cold to temperate climatic conditions (Hussey and Janssen, 2002). This situation favors their distribution in the Southern zone of Chile, where

Received 12 August 2008. Accepted 27 December 2008.

Corresponding author: lbohm@uach.cl
Meloidogyne spp. infect, among other crops, bean, carrot, clovers, lettuce, pea, potato, sugar beet, and tomato (Böhm, 1986 and Barría, 1997; Magunacelaya and Dagnino, 1999).

Management for the control of root-knot gall nematodes is traditionally performed with cultural control methods, using resistant species or resistant cultivars, and with nematicide applications (Hussey and Janssen, 2002). The use of chemical nematicides is currently questioned due to their adverse effects in agroecosystems and because of their high cost and lack of specificity towards the different types of nematodes (Soler-Serratosa et al., 1996; Chitwood, 2002). 
The current tendency is to use integrated control methods, integrating the use of antagonistic organisms into cultural practices with a minimum use of chemical nematicides. Thereby, the nematode population densities are maintained under the threshold of economic damage (Galper et al., 1990; Tsay et al., 2004).

Numerous plants species producing allelochemicals with antagonistic effect towards certain populations of plant parasitic nematodes have been reported worldwide (Chitwood, 2002). Many of these plants have been evaluated for their use in crop rotation, as cover crops or as green manure in arable soils. Additionally, plant extracts from allelopathic species (e.g., Azadirachta indica (neem), Tagetes spp., Brassica spp.) have been tested for their use as nematicides (Akhtar and Alam, 1993; Akhtar and Mahamood, 1994, 1996; Walia and Gupta, 1995; Mareggiani et al., 1998; Chitwood, 2002; Insunza et al., 2001; Oka and Yermiyahu, 2002; Tsay et al., 2004; Walker, 2004). The nematicidal effect of these extracts can be ascribed to the presence of phytochemical compounds in their tissues or to the result of the degradation process, like some polythienyls, isothiocyanates and glucosinolates (Chitwood, 2002; Stirling and Stirling, 2003).

In Chile, the nematicidal effects of different native and cultivated plants against Ditylenchus dipsaci (Kuhn), Xiphinema index Thorne-Allen and $X$. americanum sensu lato Cobb have been evaluated (Insunza and Valenzuela, 1995; Insunza and Aballay, 1995; Insunza et al., 2001; Aballay and Insunza, 2002). Their results are in accordance with the results by Halbrendt (1996) and Chitwood (2002) that suggest that the nematicidal properties of plant species vary considerably with plant species and cultivar, the plant tissue used, plant growth and development, application methods and the nematode species tested.

Antihelmintic properties have been ascribed to a diversity of native plant species in Chile, especially the tree species. Therefore, the objective of this study was to evaluate the nematicidal effect of dry foliage obtained from eight common tree species and bush-like species in Southern Chile against M. hapla.

\section{Materials and methods}

\section{Plant species}

Leaves obtained from Buddleja globosa Hoppe ("matico"), Drymis winteri J.R. Foster ("canelo"), Eucalyptus globulus Labill (eucalyptus), Gevuina avellana Mol. (Chilean hazelnut), Laurelia sempervirens Ruiz et Pav. Tul. ("laurel"), Luma apiculata Burret (Chilean myrtle), Maytenus boaria Mol. ("maitén") and Ugni molinae Turz. ("murta") were used. Leaves were collected from the Universidad Austral de Chile Arboretum, located in the North sector of Isla Teja, Valdivia, during December of 2007. Shoots were cut from the middle sections of plants of each species. Only shoots with leaves from the current season, completely expanded and apparently healthy, were taken.

The leaves were washed and left to dry at room temperature (about $20^{\circ} \mathrm{C}$ ) for 20 days on plastic trays that had been disinfected with $70 \%$ ethanol. Then, the leaves were ground $(<1 \mathrm{~mm}$ pieces) in an electric mill (ZM1, Retch $\mathrm{GmbH}$, Haan, Germany), incorporated into $200 \mathrm{~mL}$ pots containing a sandy soil substrate (1:2, sand:soil), watered and maintained at room temperature for 15 days in order to allow the interaction of the soil components with the plant tissue.

For each plant species, with the exception of $B$. globosa, 1.0, 2.5, and 5.0\% (w/w) of plant tissue were mixed with $200 \mathrm{~g}$ of soil (Santa Rosa Serie). Because of its spongy texture, $B$. globosa was mixed in proportions of $0.5,1.0$, and $2.5 \%$ to avoid exceeding $200 \mathrm{~mL}$. Control treatments consisted of the same soil substrate without the incorporation of plant tissue, but with equal inoculation with M. hapla.

\section{Inoculum of Meloidogyne hapla}

A pure population of $M$. hapla originally obtained from Paeonia lactiflora Pall. roots were used as the source of inoculum. The population was multiplied successively in tomato plants and cultivated in autoclaved sandy soil substrate 
(1:1, sand:soil). The roots were processed following the methodology by Hussey and Barker (1973), and a final suspension of 1000 eggs and juveniles per $\mathrm{mL}$ of water was obtained for inoculum.

\section{Pot preparation}

A total of 130 pots, each containing $200 \mathrm{~mL}$ of soil, were used. A lettuce plant (Lactuca sativa L. var. Reina de Mayo) obtained from seedbed prepared on sterilized soil was transplanted into each pot about 20 days after emergence, when the lettuce were $5 \mathrm{~cm}$ high. After $48 \mathrm{~h}$ from transplanting, each pot was inoculated with a fresh suspension of 2000 eggs and juveniles of M. hapla. The inoculum was distributed with a micropipette into two 2-cm-deep holes around the roots, and subsequently they were covered with soil and sealed with a light irrigation.

After inoculation, the pots were arranged on plastic dishes to avoid cross contamination through the drainage, and they were maintained in a greenhouse $\left(21 \pm 5{ }^{\circ} \mathrm{C}\right)$ for 45 days, irrigating periodically according to the plants' requirements.

\section{Evaluations}

Evaluations were performed 45 days after inoculation. For this purpose, the roots were analyzed visually to determine the galling index on a scale from 0 to 4 , where $0=$ no galls (healthy root system, no infestation); $1=1-5$ small galls (1-25\% of root system galled); $2=2-15$ small galls (26-50\% of root system galled); $3=16-25$ galls, majority of roots still functioning (56$75 \%$ of root system galled); $4=>26$ galls $(>76 \%$ of root system galled) (Hussey and Janssen, 2002).

The reproduction level reached by the nematode population was estimated from the number of propagules extracted from the egg masses that developed in the roots. The whole root system from each plant was processed by the method for the extraction of eggs and juveniles proposed by Hussey and Barker (1973). Two 1-mL aliquots were counted for each replicate, and the total number of juveniles in $100 \mathrm{~mL}$ of soil was calculated by multiplying the average of the two aliquots by 10 . The rate of reproduction (RR) was calculated as $\mathrm{RR}=\left(\mathrm{Pf}^{\mathrm{P}} \mathrm{P}^{-1}\right) \times 100$, where $\mathrm{Pf}=$ total of final propagules in the roots and $\mathrm{Pi}=2000$ eggs and juveniles inoculated per pot.

\section{Design and statistical analysis}

Treatments were distributed according to an 8 x 3 factorial design (eight plant species x three plant tissue concentrations), replicated five times. The experimental unit consisted of one pot per replicate. The results were analyzed for variance and means were tested for significant differences by the least significant difference (LSD), using the program JMP6 (SAS Inc., USA).

\section{Results}

The incorporation of leaves of $L$. sempervirens ("laurel") into the soil significantly diminished $(\mathrm{p} \leq 0.05)$ the formation of galls caused by $M$. hapla in lettuce roots. Likewise, the foliar tissue of $G$. avellana (Chilean hazelnut) and $M$. boaria ("maitén") reduced the number and percentage of root galling, while only the percentage of root galling decreased in lettuce plants grown in soil substrate amended with leaves of D. winteri ("canelo") and B. globosa ("matico") (Figures 1A and 1B). On the other hand, U. molinae ("murta"), E. globulus (eucalyptus) and $L$. apiculata (Chilean myrtle) leaves had a weak, non-significant effect on gall formation, associated with a severe or high infestation in the lettuce roots (Figure 1).

Independent of the plant species, the incorporation of dry plant tissues negatively affected the reproduction of $M$. hapla in lettuce, reducing the number of eggs and the formation of second stage juveniles significantly ( $\mathrm{p} \leq 0.05)$ (Figures $1 \mathrm{C}$ and $1 \mathrm{D})$. The treatments containing dry foli- 
A

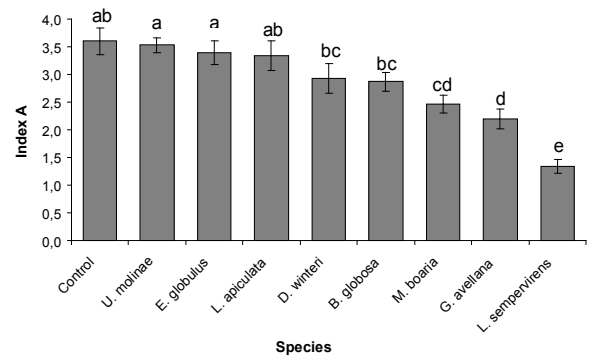

$\mathrm{C}$

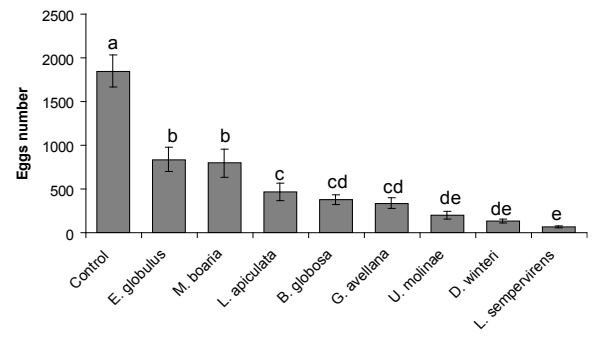

B

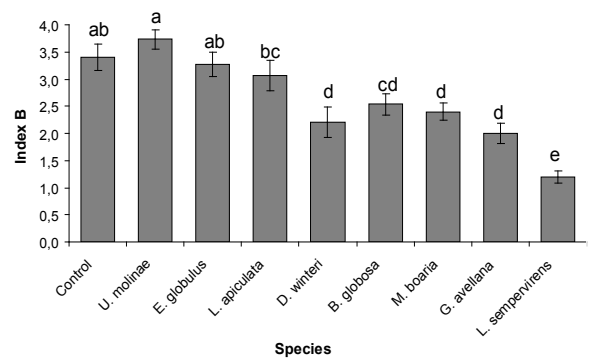

$\mathrm{D}$

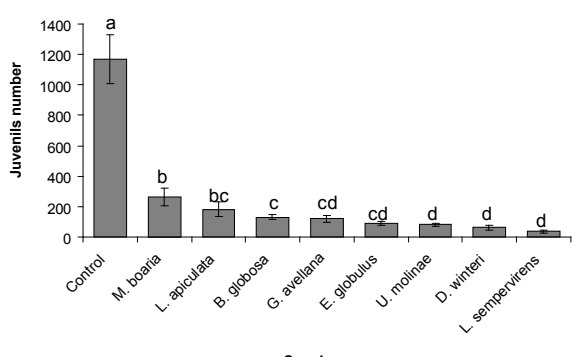

Figure 1. Effects of dry leaf tissues obtained from eight Chilean native plant species on Meloidogyne hapla in roots of lettuce (Lactuca sativa). A. Galling index by root-knot number, B. Galling index by root-knot percentage, C. Eggs, and D. Second stage juveniles. Bars followed by different letters indicate significant statistical differences according to the least significant difference (LSD) test $(\mathrm{p} \leq 0.05)$.

age of E. globulus (eucalyptus) and M. boaria ("maitén") reduced the presence of $M$. hapla eggs by more than $50 \%$ compared to the nonamended controls. In soil amended with L. apiculata (Chilean myrtle), B. globosa ("matico") and $G$. avellana (Chilean hazelnut), egg production was reduced by more than $30 \%$. Ugni molinae ("murta"), D. winteri ("canelo"), and $L$. sempervirens ("laurel") foliage had the highest impact on the reproductive activity of M. hapla in lettuce (Figure 1C). Likewise, the number of juveniles II was significantly reduced $(\mathrm{p} \leq 0.05)$ with respect to the control non-amended treatments. There were significant differences among the plant species, and the dry leaf tissues of $U$. molinae, D. winteri, and L. sempervirens had the highest impacts, with less than 100 juveniles II of M. hapla per root system (Figure 1D).

The variance analysis shows that for each plant species there were significant differences between the levels of control of M. hapla by different concentrations of plant leaf incorporated into the soil, although the magnitude of this effect differs depending on the plant species (Table 1).

For each species, an increase in the concentration of plant tissue incorporated into the soil substrate resulted in a reduction in the reproductive activity of M. hapla. Therefore, in most plant species, $5 \%$ concentrations $(10 \mathrm{~g})$ had the greatest effect on the reproductive indexes. However, significant differences $(\mathrm{p} \leq 0.05)$ among the plant species were not detected when the highest foliage concentration was incorporated into the soil substrate (Table 1). On the other hand, the responses of the reduction of eggs and juveniles varied according to the plant species when $1 \%$ of dry plant tissue was used, with L. sempervirens ("laurel") having the best effect. The effect of adding $1 \%$ of dry leaf tissue of $L$. sempervirens ("laurel") was not significantly different from the effect obtained with other plant species at $5 \%$ concentrations (Table 1 ).

In the special case for B. globosa ("matico"), the $0.5 \%$ concentration ( $2 \mathrm{~g}$ of dry leaf tissue) 
Table 1. Effects of soil amended with three concentrations of dry leaf tissues obtained from Chilean native plant species against Meloidogyne hapla in lettuce (Lactuca sativa).

\begin{tabular}{|c|c|c|c|c|}
\hline \multirow[b]{2}{*}{ Species } & \multirow[b]{2}{*}{ Concentration \% } & \multicolumn{3}{|c|}{ Mean $( \pm \text { standard error })^{1}$} \\
\hline & & Eggs, no. & Juveniles, no. & Total, no. \\
\hline \multirow[t]{3}{*}{ Buddleja globosa } & 0.5 & $612 \pm 90.0 \mathrm{e}$ & $186 \pm 22.0 \mathrm{de}$ & $798 \pm 75.5$ ef \\
\hline & 1.0 & $328 \pm 33.7 \mathrm{fg}$ & $138 \pm 14.6 \mathrm{def}$ & $466 \pm 40.0 \mathrm{~g}$ \\
\hline & 2.5 & $182 \pm 22.4$ fghi & $70 \pm 11.4$ def & $252 \pm 24.0$ ghi \\
\hline \multirow[t]{3}{*}{ Drymis winteri } & 1.0 & $166 \pm 30.4$ fghi & $102 \pm 26.5 \mathrm{def}$ & $268 \pm 56.3 \mathrm{ghi}$ \\
\hline & 2.5 & $190 \pm 34.8$ fghi & $68 \pm 21.0$ def & $258 \pm 51.8$ ghi \\
\hline & 5.0 & $42 \pm 8.0 \quad$ hi & $16 \pm 5.1 \quad \mathrm{f}$ & $58 \pm 12.4 \mathrm{i}$ \\
\hline \multirow[t]{3}{*}{ Eucalyptus globulus } & 1.0 & $1440 \pm 69.9 \quad b$ & $144 \pm 20.1$ def & $1584 \pm 81.7 \quad b$ \\
\hline & 2.5 & $898 \pm 52.0 \mathrm{~d}$ & $72 \pm 23.5$ def & $970 \pm 71.8 \mathrm{de}$ \\
\hline & 5.0 & $178 \pm 4.4$ fghi & $52 \pm 177$ def & $230 \pm 41.8$ ghi \\
\hline \multirow[t]{3}{*}{ Gevuina avellana } & 1.0 & $608 \pm 58.6$ e & $196 \pm 44.8 \mathrm{~cd}$ & $804 \pm 93.1$ ef \\
\hline & 2.5 & $270 \pm 56.8$ ghi & $122 \pm 31.5 \mathrm{def}$ & $392 \pm 65.4 \mathrm{gh}$ \\
\hline & 5.0 & $130 \pm 31.1$ fghi & $42 \pm 11.6$ ef & $172 \pm 37.3$ ghi \\
\hline \multirow[t]{3}{*}{ Laurelia sempervirens } & 1.0 & $124 \pm 13.3$ ghi & $68 \pm 22.2$ def & $192 \pm 30.4$ ghi \\
\hline & 2.5 & $30 \pm 15.2 \quad \mathrm{i}$ & $18 \pm 8,6 \quad \mathrm{f}$ & $48 \pm 23.5 \quad \mathrm{i}$ \\
\hline & 5.0 & $44 \pm 6.0 \quad$ hi & $28 \pm 5.8 \quad \mathrm{f}$ & $72 \pm 11.1 \mathrm{hi}$ \\
\hline \multirow[t]{3}{*}{ Luma apiculata } & 1.0 & $912 \pm 155.3 \mathrm{~d}$ & $334 \pm 121.4 \mathrm{bc}$ & $1246 \pm 227.3 \mathrm{~cd}$ \\
\hline & 2.5 & $290 \pm 49.2 \mathrm{fgh}$ & $136 \pm 29.4 \mathrm{def}$ & $426 \pm 59.8 \mathrm{~g}$ \\
\hline & 5.0 & $188 \pm 44.6$ fghi & $78 \pm 24.2$ def & $266 \pm 59.4$ ghi \\
\hline \multirow[t]{3}{*}{ Maytenus boaria } & 1.0 & $1208 \pm 284.1 \mathrm{bc}$ & $334 \pm 70.9 \quad b c$ & $1542 \pm 252.4 \mathrm{bc}$ \\
\hline & 2.5 & $1040 \pm 177.7 \mathrm{~cd}$ & $400 \pm 106.1 \mathrm{~b}$ & $1440 \pm 271.3 \mathrm{bc}$ \\
\hline & 5.0 & $140 \pm 44.4$ fghi & $52 \pm 19.3 \mathrm{def}$ & $192 \pm 46.7$ ghi \\
\hline \multirow[t]{3}{*}{ Ugni molinae } & 1.0 & $386 \pm 94.4$ ef & $108 \pm 23.5 \mathrm{def}$ & $494 \pm 97.0 \mathrm{fg}$ \\
\hline & 2.5 & $108 \pm 16.8$ ghi & $66 \pm 14.3 \mathrm{def}$ & $174 \pm 29.1$ ghi \\
\hline & 5.0 & $98 \pm 23.1$ ghi & $70 \pm 13.8$ def & $168 \pm 33.7$ ghi \\
\hline Control & 0.0 & $1848 \pm 180.3 \mathrm{a}$ & $1166 \pm 160.9 \mathrm{a}$ & $3014 \pm 294.7 \mathrm{a}$ \\
\hline \multicolumn{5}{|l|}{ Analysis of variance } \\
\hline Cause of variation & d.f. & $\mathrm{F}(\mathrm{p})$ & $\mathrm{F}(\mathrm{p})$ & $\mathrm{F}(\mathrm{p})$ \\
\hline Plant species (S) & 7 & $33.13(<0.0001)$ & $9.25(<0.0001)$ & $21.80(<0.0001)$ \\
\hline Concentrations (C) & 2 & $82.35(<0.0001)$ & $20.95(<0.0001)$ & $11.89(<0.0001)$ \\
\hline $\mathrm{S} \times \mathrm{C}$ & 14 & $7.74(<0.0001)$ & $2.63(<0.0028)$ & $3.68(<0.0001)$ \\
\hline
\end{tabular}

${ }^{1}$ Means followed by different letters in each column are statistically different according to the least significant difference (LSD) test (p $\leq$ $0.05)$. 
reduced the number of eggs by almost $30 \%$ and the presence of juveniles II of M. hapla by six times, respectively, compared to the nonamended control. The decrease in the formation of eggs was more than double the impact accomplished with the $1 \%$ dry leaf tissue of $E$. globulus (eucalyptus) and M. boaria ("maitén"). These differences were significant $(\mathrm{p} \leq 0.05)$ (Table 1).

\section{Discussion}

Considering that there was a significant reduction in the galling and reproductive activity of $M$. hapla, the detrimental effect of the foliar dry tissue from the different plant species evaluated against $M$. hapla was clearly demonstrated.

This is one of the first studies to evaluate the effect of dry leaf tissues from some native Chilean species against M. hapla. Previous works have shown that certain native species (e.g., Aristotelia chilensis, Cestrum parqui, Quillaja saponaria, Chenopodium ambrosioides, Oxalis rosea, and Ovidia pillopillo) have nematostatic or nematicidal effects against Ditylenchus dipsaci, M. incognita, and Xiphinema americanum sensu lato (Insunza and Valenzuela, 1995; Insunza et al., 2001).

It is noticeable that native species like L. sempervirens ("laurel") cause the highest reduction in the gall indexes of lettuce roots. In addition, laurel showed a significant effect on altering the reproductive activity of $M$. hapla. These effects are in concordance with previous findings indicating that the essential oils of $L$. sempervirens have growth regulatory, insecticidal and acaricidal activity (Neira et al., 2004; Torres et al., 2004). Although the identities of the compounds that reduce the presence of eggs and juveniles of M. hapla in the present test are unknown, Schmeda-Hirschmann et al. (1994, 1996) have reported the presence of alkaloids (e.g., laurotetanine and seco-isotetrandrine) in L. sempervirens leaves. In addition, safrole and eugenol derivatives have been isolated (Neira et al., 2004); insecticidal properties have been reported for both compounds (Huang et al., 1999; Huang et al., 2002). Likewise, the effects asserted on the presence of M. hapla by U. molinae ("murta") and D. winteri ("canelo") were not significantly different from the effects of laurel, and even these effects were similar in presence of juveniles II (Figure 1).

On the other hand, extracts obtained from "murta" have been widely used in the pharmaceutical industry because of their medicinal activity, mainly associated with the polyphenolic compounds present in the leaves (Rubilar et al., 2006). Some polyphenols are secondary metabolites that defend the plant against infections caused by microorganisms (Heath, 2002), which suggests that some compounds of this nature assert negative effects on M. hapla. In addition, other extracts from Myrtaceae leaves as well as E. globulus leaves (eucalyptus) have been used as antibacterial components, where the main active ingredient is eucalyptol $(1,8$ cineole) (Salari et al., 2006). The 1,8-cineole has been reported to have a high insecticidal activity against fruit flies (Clemente et al., 2007). In addition, $\alpha$-pinene extracted from eucalyptus leaves has shown some effect on reducing egg enclosion in M. incognita (Ibrahim et al., 2006). The compound $\alpha$-pinene has also been detected in Chilean myrtle (L. apiculata), a species that also contains flavonoids (e.g., quercitin, kaempferol, mirecitin), cineole and myrtol (Montes and Wilkomirsky, 1985; Hoffmann et al., 1992). Some flavonoids (e.g., kaempferol) considerably inhibit the development of lepidopteran larvae (Onyilagha et al., 2004).

According to Williams and Harvey (1982), Montes and Wikomirsky (1985) and Hoffmann et al. (1992), D. winteri ("canelo") leaves contain different essential oils such as ascaridole, pinene, limonene and eugenol. In addition, they have tannins, terpenoids (e.g., drimenol, drimenine, cryptomeridiol, winterine) and flavonoids (e.g., cirsimaritine, taxifoline, quercitin, kaempferol). Drymis winteri ("canelo") extracts have been used for insect control (Torres et al., 2004), and ascaridole derivatives have shown nematicidal activity against Aphelenchoides besseyi and $M$. incognita, with better results against this last species (Yen et al., 2007).

In G. avellana (Chilean hazelnut), the identification of active compounds has been focused on the fruit (nut), mainly to study the content of 
fatty acids as a source of antioxidants (Bertoli et al., 1998; Moure et al., 2000). The possible active components present in the leaves have not been identified yet. However, the presence of phenolic and tannin compounds, which may have a direct effect on $M$. hapla, has been characterized (Chacón and Armesto, 2006).

The concentrations of flavonoids and tannins in B. globosa ("matico") are remarkable (Vogel et al., 2004). The presence of terpene compounds (e.g., buddlejone, deoxybuddlejone, buddledin-A, buddledin-B and maytenone) with high antifungal activities against dermatophytes has also been reported (Mensah et al., 2000), where buddledin-A is the main compound responsible (Houghton et al., 2003). Likewise, daucosterine, dulcitol, lupenone, $\beta$-amyrine, oleanoic acid, $\beta$-sitosterol and $\alpha$-spinasterol have been isolated from M. boaria ("maitén") leaves and roots (Hoffmann et al, 1992), but there are not data on the effects of these compounds on nematodes. However, $\beta$-dihydroagarofuran obtained from $B$. globosa ("matico") seeds has an inhibitory effect on Spodoptera frugiperda (Lepidoptera) and causes 100\% larval mortality (Céspedes et al., 2001).
The nematicidal activity on eggs and juveniles II of M. hapla obtained from the dry plant tissues in this study may serve for the eventual development of biocides. The nematicidal activity of these plant extracts may be due to either a single, or more than one compound and an interaction among compounds is also possible. Further research is needed to clarify this point. However, the data show that all of the dry plant tissues evaluated may be used for the integrative control of M. hapla.

In conclusion, all of the dry leaf extracts of the plant species used in this study exerted control on $M$. hapla, reducing gall formation and the presence of eggs and juveniles, with the best results shown by the native Chilean species like $L$. sempervirens ("laurel") D. winteri ("canelo"), and $U$. molinae ("murta").

\section{Acknowledgment}

This study was financed by the Project DID 2007-26, Universidad Austral de Chile, Valdivia, Chile.

\section{Resumen}

L. Böhm, N. Arismendi y L. Ciampi. 2009. Actividad nematicida del follaje de especies arbóreas y arbustivas comunes del sur de Chile sobre Meloidogyne hapla. Cien. Inv. Agr. 36 (2): 249-258. Buscando alternativas biológicas para el control del nemátodo de las agallas radicales, Meloidogyne hapla, se evaluó la incorporación al sustrato de follaje seco y molido de Buddleja globosa, Drymis winteri, Eucalyptus globulus, Gevuina avellana, Laurelia sempervirens, Luma apiculata, Maytenus boaria y Ugni molinae. Se utilizó como control un tratamiento sin follaje. El ensayo se realizó en macetas en las que se trasplantaron plantas de lechuga (cv. Reina de Mayo). Todas las macetas se inocularon con 2000 huevos y juveniles de M. hapla y se mantuvieron por 45 días en invernadero. Los resultados indicaron que las plantas de lechuga desarrolladas en sustratos con hojas secas de L. sempervirens, G. avellana, $M$. boaria, $D$. winteri y $B$. globosa redujeron significativamente el agallamiento radical. Mientras que todos los tratamientos afectaron significativamente la formación de huevos y juveniles de M. hapla, destacando el efecto inhibitorio sobre este parámetro el follaje seco de U. molinae, $D$. winteri y L. sempervirens. En todas las especies, el incremento de la concentración de follaje incorporado al sustrato resultó en un mayor control en la multiplicación de M. hapla.

Palabras clave: Arboles nativos, control biológico, especies forestales, Meloidogyne hapla, nematodos. 


\section{References}

Aballay, E., and V. Insunza. 2002. Evaluación de plantas con propiedades nematicidas en el control de Xiphinema index en vid de mesa cv. Thompson Seedless en la zona central de Chile. Agricultura Técnica 62:357-365.

Akhtar, M., and M. Alam. 1993. Utilization of waste materials in nematode control: a review. Bioresource Technology 45:1-7.

Akhtar, M., and I. Mahmood. 1994. Nematode populations and short-term tomato growth in response to neem-based products and other soil amendments. Nematropica 24:169-173.

Akhtar, M., and I. Mahmood. 1996. Effect of a plant based product "neem" and some plant oil on Nematodes . Nematologia Mediterranea 24:3-5.

Bertoli, C., L.B. Fay, M. Stancanelli, D. Gumy, and P. Lambelet. 1998. Characterization of Chilean hazelnut (Gevuina avellana Mol) seed oil. Journal of the American Oil Chemists' Society (JAOCS) 75:1037-1040.

Böhm, L. 1986. Evaluación de la resistencia a Meloidogyne incognita (Kofoid \& White), en clones del germoplasma chileno de papas. AgroSur (Chile) 14:127-130.

Céspedes C.L., J. Alarcón, E. Aranda, J. Becerra, and M. Silva. 2001. Insect growth regulator and insecticidal activity of beta-dihydroagarofurans from Maytenus spp. (Celastraceae) (abstract). Zeitschrift für Naturforschung - C. Journal of Biosciences 56:603-613.

Chacón, P., and J. Armesto. 2006. Do carbon-based defences reduce foliar damage? Habitat-related effects on tree seedling performance in a temperate rainforest of Chiloe' Island, Chile. Oecologia 146:555-565.

Chitwood, D.J. 2002. Phytochemical based strategies for nematode control. Annual Review of Phytopathology 40:221-249.

Clemente, S.V., G. Mareggiani, A. Broussalis, and G. Ferraro. 2007. Actividad insecticida de 1,8cineol sobre mosca de los frutos, Ceratitis capitata Wied. (Diptera: Tephritidae). Dominguezia 23:29-34.

Galper, S., E. Cohn, Y. Spiegel, and I. Chei. 1990. Nematicidal effect of collagen-amended soil and the influence of protease and collagenase. Revue Nematologie 13:67-71.

Halbrendt, J.M. 1996. Allelopathy in the management of plant-parasitic nematodes. Journal of
Nematology 28:8-14.

Heath, M. 2002. Secondary metabolites and plant defense. Physiological and Molecular Plant Pathology 60:273-274.

Hoffmann, A., C. Farga, J. Lastra, and E. Veghazi. 1992. Plantas medicinales de uso común en Chile. Ediciones Fundación Claudio Gay. Santiago, Chile. $267 \mathrm{p}$.

Houghton, P.J., A.Y. Mensah, N. Iessa, and Y.H. Hong. 2003. Terpenoids in Buddleja: relevance to chemosystematics, chemical ecology and biological activity. Phytochemistry 64:385-393.

Huang, Y., S.H. Ho, and R.M. Kini. 1999. Bioactivities of safrole and isosafrole on Sitophilus zeamais (Coleoptera: Curculionidae) and Tribolium castaneum (Coleoptera: enebrionidae). Journal of Economic Entomology 92:676-683.

Huang, Y., S.H. Ho, H.C. Lee, and Y.L. Yap. 2002. Insecticidal properties of eugenol, isoeugenol and methyleugenol and their effects on nutrition of Sitophilus zeamais Motsch. (Coleoptera: Curculionidae) and Tribolium castaneum (Herbst) (Coleoptera: Tenebrionidae). Journal of Stored Products Research 38:403-412.

Hussey, R.S., and K. Barker. 1973. A comparison of methods of collecting inocula for Meloidogyne spp., incluiding a new technique. Plant Disease Reporter 57:1025-1028.

Hussey, R.S., and G.J.W. Janssen. 2002. Root-knot nematodes: Meloidogyne species. Pages 43-70. In: J.L. Starr, R. Cook, and J. Bridge, (eds.). Plant Resistance to Parasitic Nematodes. CAB International, London, England.

Ibrahim, S.K., A.F. Traboulsi, and S. El-Haj. 2006. Effect of essential oils and plant extracts on hatching, migration and mortality of Meloidogyne incognita. Phytopathologia Mediterranea 45:238-246.

Insunza, V., and E. Aballay. 1995. Evaluación de 16 plantas con propiedades nematicidas como hospederos de Xiphinema americanum sensu lato en Chile. Investigación Agrícola (Chile) 15:39-42.

Insunza, V., and A. Valenzuela. 1995. Control of Ditylenchus dipsaci in garlic (Allium sativum) with extracts of medicinal plants from Chile. Nematrópica 25:35-41.

Insunza, V., E. Aballay, and A.J. Macaya. 2001. In vitro nematicidal activity of aqueous plant extracts of chilean populations of Xiphinema amaricanum sesu latu. Nematropica 31:47-54.

Magunacelaya, J.C., and E. Dagnino. 1999. Nematología agrícola en Chile. Serie Ciencias 
Agronómicas $\mathrm{N}^{\circ}$ 2. Universidad de Chile. Santiago, Chile. 282 p.

Mareggiani, G., S. Leicach, and P. Laner. 1998. Toxicidad de extractos que contienen metabolitos secundarios de distintos órganos de Melia azedariach $\mathrm{L}$. al nemátodo del nudo de la raíz. Fitopatología 33:122-129.

Mensah, A.Y., P.J. Houghton, S. Bloomfield, A. Vlietinck, and D. Vanden Berghe. 2000. Known and novel terpenes from Buddleja globosa displaying selective antifungal activity against Dermatophytes. Journal of Natural Products 63:12101213.

Montes, M., and T. Wilkomirsky. 1985. Medicina Tradicional Chilena. Ediciones Universidad de Concepción. Concepción, Chile. 206 p.

Moure, M., D. Franco, J. Sineiro, H. Domínguez, M.J. Núñez, and J.M. Lema. 2000. Evaluation of Extracts from Gevuina avellana Hulls as Antioxidants. Journal of Agriculture and Food Chemistry 48:3890-3897.

Neira, N., P. Heinsohn, and R. Carrillo. 2004. Efecto de aceites esenciales de lavanda y laurel sobre el ácaro Varroa destructor Anderson \& Truemann (Acari:Varroidae). Agricultura Técnica (Chile) 64:238-244.

Oka, Y., and U. Yermiyahu. 2002. Suppressive effects of composts against the root-knot nematode Meloidogyne javanica on tomato. Nematology 4:891-898.

Onyilagha, J.C., J. Lazorko, M.J. Gruber, J.J. Soroka, and M.A. Erlandson. 2004. Effect of flavonoids on feeding preference and development of the crucifer pest Mamestra configurata Walker. Journal of Chemical Ecology 30:109-124.

Rubilar, R., M. Pinelo, M. Ihl, E. Scheuermann, J. Sineiro, and M.J. Núñez. 2006. Murta leaves (Ugni molinae Turcz.) as a source of antioxidant polyphenols. Journal of Agricultural and Food Chemistry 54:59-64.

Salari, M.H., G. Amine, M.H. Shirazi, R. Hafezi, and M. Mohammadypour. 2006. Antibacterial effects of Eucalyptus globulus leaf extract on pathogenic bacteria isolated from specimens of patients with respiratory tract disorders. Clinical Microbiology and Infection 12:194-196.

Schmeda-Hirschmann, G., M. Dutra-Behrens, G. Habermehl, and J. Jakupovic. 1996. Seco-isotetrandrine from Laurelia sempervirens. Phytochemistry 41:339-341.
Schmeda-Hirschmann, G., J. Loyola, J. Rodríguez, and M. Dutra-Behrens. 1994. Hypotensive effect of Laurelia sempervirens (Monimiaceae) on normotensive rats. Phytotherapy Research 8:49-51.

Soler-Serratosa, A., N. Kokalis-Bureli, R. RodríguezKabana, C. Weaver, and P.S. King. 1996. Allelochemicas for control of plant-parasitic nematodes: In vivo nematicidal efficacy of thymolbenzaldehide combinations. Nematropica 26:5771.

Stirling, G., and A. Stirling. 2003. The potential of Brassica green manure crops for controlling root-knot nematode (Meloidogyne javanica) on horticultural crops in a subtropical environment. Australian Journal of Experimental Agriculture 46:623-630.

Tsay, T., S. Wu, and Y. Lin. 2004. Evaluation of Asteraceae Plants for Control of Meloidogyne incognita. Journal of Nematology 36:36-41.

Torres, P., J.Marín, J.Becerra, E. Aranda, and C. Céspedes, C. 2004. Insecticidal and growth regulatory activities of essential oil from Chilean natives Magnoliidae. PO-128 (Summary). In: XIII Congreso Italo-latino americano di Etnomedicina "Paolo Ceccherelli". Salerno, Italy 22-25 September 2004.

Vogel, H., I. Razmilic, and B. González. 2004. Matico (Buddleja globosa Hope): evaluación de diferentes accesiones, número de cosechas, humedad del suelo y extracción de nutrientes. Agricultura Técnica (Chile) 64:413-420.

Walia, K.K. and D.C. Gupta. 1995. Neem - an effective biocide against Meloidogyne javanica affecting vegetable crops. Plant Disease Research 10:50-61.

Walker, G.E. 2004. Effects of Meloidogyne javanica and organic amendments, inorganic fertilizers and nematicides on carrot growth and nematode abundance. Nematologia Mediterranea 32:181188.

Williams, C. and W. Harvey. 1982. Leaf flavonoid patterns in the Winteraceae. Phytochemistry 21:329-337.

Yen, Y., M.J. Yeh and W.F. Hsiao. 2007. Synthesis and nematicidal activity of ascaridole derivatives against Meloidogyne incognita and Aphelenchoides besseyi. Journal of Pesticide Science 32:49-52. 
